\title{
Staphylococcus Aureus Isolados de Linguiças Suínas e de Frango do Tipo Frescal: Antibiograma e Tipificação Microbiana
}

Larissa Gomes Bernardo (I), Samira Obeid Georges (I), Liana Jayme Borges (I), Maria Cláudia Dantas Porfírio Borges André (I)

(I) UFG - UNIVERSIDADE FEDERAL DE GOIÁS (Rua 227 Qd. 68 s/nํ- Setor Leste Universitário - Goiânia, GO)

\section{Resumo}

INTRODUÇÃO: A linguiça do tipo frescal é um dos produtos cárneos mais consumidos no Brasil, exigindo poucos recursos tecnológicos para sua produção. Devido à presença de condimentos e a recomendação de conservação sob refrigeração, espera-se baixa contaminação microbiológica neste alimento. Porém, por ser um produto in natura altamente manipulado e sabendo-se que as condições de produção da linguiça nem sempre atendem as recomendações das Boas Práticas de Fabricação, bactérias potencialmente patogênicas como Staphyloccocus aureus que entre outros fatores de virulência, é produtora de enterotoxinas, pode encontrar condições de sobrevivência e multiplicação se atingir o alimento em qualquer etapa da sua produção. OBJETIVO: Isolar e identificar S. aureus a partir de amostras de linguiça frescal do tipo suína e de frango, determinar o perfil de suscetibilidade a antimicrobianos e a similaridade genética dos isolados. MÉTODOS: Foram coletadas 86 amostras em açougues do Município de Aparecida de Goiânia (GO), entre julho e agosto de 2013. As análises microbiológicas obdeceram a metodologia oficial prevista na American Public Health Association. Após a identificação, foi realizado o antibiograma pela técnica de disco-difusão e a tipagem microbiana por eletroforese em gel em campo pulsado (PFGE). RESULTADOS: Das amostras coletadas seis $(6,98 \%)$ apresentaram contaminação por S. aureus, sendo obtidos sete isolados. Destes, cinco em

\footnotetext{
Referência:

Larissa Gomes Bernardo, Samira Obeid Georges, Liana Jayme Borges, Maria Cláudia Dantas Porfírio Borges André. Staphylococcus Aureus Isolados de Linguiças Suínas e de Frango do Tipo Frescal: Antibiograma e Tipificação Microbiana. In: Anais do $12^{\circ}$ Congresso Latinoamericano de Microbiologia e Higiene de Alimentos - MICROAL 2014 [= Blucher Food Science Proceedings, num.1, vol.1]. São Paulo: Editora Blucher, 2014.

DOI 10.5151/foodsci-microal-133
} 
linguiça de frango e dois em linguiça suína. Um isolado (14,3\%) obtido de linguiça de frango foi resistente à penicilina. Três isolados $(42,9 \%)$ sendo dois de linguiça de frango e um de linguiça suína apresentaram suscetibilidade intermediária à clindamicina. Três isolados de linguiças de marcas diferentes, coletadas em açougues diferentes apresentaram 100\% de similaridade pela técnica de PFGE. Uma amostra mostrou-se contaminada por dois isolados diferentes geneticamente. CONCLUSÃO: A presença de S. aureus neste alimento denota risco microbiológico, pois não se pode garantir que sua multiplicação e produção de toxinas poderá ser evitada até o momento do consumo. Isolados geneticamente idênticos identificados em açougues diferentes e de marcas diferentes, indicam origem comum de contaminação. As condições gerais de higiene e processamento destes alimentos podem comprometer a qualidade do produto final e ocasionar riscos ao consumidor.

Palavras-Chave: S.aureus, Linguiça frescal, Tipagem, Antimicrobianos Agência de Fomento: 